\title{
UJI AKTIVITAS ANTIBAKTERI NANOPARTIKEL EKSTRAK LENGKUAS PUTIH (Alpinia galanga (L.) Willd) TERHADAP BAKTERI Klebsiella pneumoniae
}

\author{
Selphina Kumowal ${ }^{1}$, Fatimawali $^{1)}$, Imam Jayanto ${ }^{\text {1) }}$ \\ ${ }^{1)}$ Program Studi Farmasi FMIPA UNSRAT Manado, 95115
}

\begin{abstract}
White galangal rhizome (Alpinia galanga (L.) Willd's) scientifically proven has properties as antibacterial, antifungal, anticancer, antitumor, antioxidant and cytotoxic. In nano size, the contact surface area of the particle becomes larger which can increase the amount of active substance which is isolated more so that the antibacterial activity is stronger. This study aims to determine whether the white galangal extract nanoparticles have antibacterial activity against the bacteria Klebsiella pneumoniae and measure the inhibitory ability of white galangal extract nanoparticles against bacterial growth and compared with white galangal ethanol extract. White galangal was extracted using maceration method with ethanol solvent and nanoparticle formulation made of white galangal extract by ionic gelation method. The antibacterial activity test was carried out using agar diffusion method and observations were made 1x24 hours incubation period, with inhibition zones measured using a millimeter ruler. The results showed that the white galangal extract nanoparticles had antibacterial activity to inhibit the bacteria Klebsiella pneumoniae, with the results of inhibition zone measurements of $22.5 \mathrm{~mm}$.
\end{abstract}

Keywords : Antibacterial, Extraction, Klebsiella pneumoniae, Nanoparticles, White galangal.

\begin{abstract}
ABSTRAK
Rimpang lengkuas putih (Alpinia galanga (L.) Willd) memiliki khasiat yang sudah dibuktikan secara ilmiah sebagai antibakteri, antijamur, antikanker, antitumor, antioksidan dan sitotoksik. Dalam ukuran nano, luas kontak permukaan partikel menjadi lebih besar yang dapat meningkatkan jumlah zat aktif yang terisolasi lebih banyak sehingga aktivitas antibakteri semakin kuat. Penelitian ini bertujuan untuk mengetahui apakah nanopartikel ekstrak lengkuas putih memiliki aktivitas antibakteri terhadap bakteri Klebsiella pneumoniae serta mengukur kemampuan daya hambat nanopartikel ekstrak lengkuas putih terhadap pertumbuhan bakteri dan dibandingkan dengan ekstrak etanol lengkuas putih. Lengkuas putih diekstraksi menggunakan metode maserasi dengan pelarut etanol dan dibuat formulasi nanopartikel ekstrak lengkuas putih dengan metode gelasi ionik. Untuk pengujian aktivitas antibakteri dilakukan dengan metode difusi agar dan pengamatan dilakukan 1x24 jam masa inkubasi, dengan zona hambat diukur menggunakan penggaris millimeter. Hasil penelitian menunjukkan bahwa nanopartikel ekstrak lengkuas putih memiliki aktivitas antibakteri untuk menghambat bakteri Klebsiella pneumoniae, dengan hasil pengukuran zona hambat sebesar $22,5 \mathrm{~mm}$.
\end{abstract}

Kata Kunci : Lengkuas putih, Nanopartikel, Antibakteri, Ekstraksi, Klebsiella pneumoniae. 


\section{PENDAHULUAN}

Nanoteknologi menjadi salah satu dalam bidang rekayasa ilmu Fisika, Kimia, Biologi yang penting dan menarik beberapa tahun terakhir ini (Kurniasari, 2016). Beberapa jenis pengembangan nanoteknologi yang sangat pesat yaitu nanomedisin, nanoemulsi dan nanopartikel. Penelitian tentang nano menjadi perhatian penting karena dapat diaplikasikan secara luas seperti dalam bidang elektronik (Hubler dan Onyeama, 2010), optik (Taylor, et al., 2013) dan biomedis (Duncan dan Michael, 2015). Nanopartikel merupakan partikel koloid padat dengan diameter 1-1000 nm (Tiyaboonchai, 2003). Bentuk dan ukuran partikel merupakan salah satu faktor yang mempengaruhi efektifitas obat. Karena ukuran partikel sangat berpengaruh dalam proses kelarutan, absorbsi dan distribusi obat (Prasetyorini, 2011).

Polimer yang digunakan untuk pembentukan nanopartikel salah satunya adalah kitosan dan Na-TPP (Natrium Tripolifosfat). Muatan positif gugus amina kitosan berinteraksi dengan muatan negatif TPP (Bhumkar dan Varsha, 2006) untuk membentuk kompleks dengan ukuran dalam rentang nanopartikel (Kafshgari, et al., 2011). Kitosan mempunyai sifat spesifik yaitu adanya sifat bioaktif, biokompatibel, pengkelat, antibakteri dan dapat terbiodegradasi (Ramadhan, et al., 2010). Dalam bentuk mikro/nanopartikel, kitosan mempunyai banyak keunggulan yakni stabil selama penggunaan, luas permukaan yang tinggi, dapat dijadikan matriks untuk berbagai jenis obat (Agnihotri, et al., 2004). Salah satu metode yang digunakan untuk pembuatan nanopartikel adalah dengan gabungan kompleks koaservasi dan gelasi ionik. Kompleks koaservasi atau gelasi ionik dapat diinduksi dalam sistem yang mempunyai dua dispersi koloid hidrofilik yang mempunyai muatan yang berlawanan. Mekanisme terbentuknya formulasi nanopartikel kitosan ini berdasarkan pada interaksi elektrostatik antara gugus amina kitosan dengan gugus bermuatan negatif dari suatu polianion (Tiyaboonchai, 2003).

Di Indonesia teknologi nanopartikel terutama untuk herbal masih dikembangkan. Penggunaan bahan alam kini semakin meningkat pemanfaatannya sebagai obat tradisional. Salah satu keanekaragaman hayati yang bermanfaat bagi kesehatan yaitu lengkuas putih. Rimpang lengkuas putih memiliki khasiat yang sudah dibuktikan secara ilmiah sebagai antibakteri, antijamur, antikanker, antitumor, antioksidan dan sitotoksik (Hernani, et al., 2007). Rimpang lengkuas putih mengandung kurang lebih $1 \%$ minyak atsiri berwarna kuning kehijauan (Sinaga, 2005). Rimpang lengkuas putih memiliki kandungan senyawa flavonoid yang diduga dapat menghambat pertumbuhan bakteri yang telah resisten terhadap antibiotik (Kusriani dan shofia, 2015). Ekstrak lengkuas putih berpotensi dalam menghambat pertumbuhan bakteri Klebsiella pneumoniae. Dalam ukuran nano, luas kontak permukaan partikel menjadi lebih besar yang dapat meningkatkan jumlah zat aktif yang terisolasi lebih banyak sehingga aktivitas antibakteri semakin kuat (Kammona dan Costas, 2012).

Berdasarkan uraian di atas, mendorong peneliti melakukan penelitian yang bertujuan untuk membuat formulasi nanopartikel ekstrak lengkuas putih dengan metode gelasi ionik. Serta melakukan uji aktivitas antibakteri dimana bakteri yang digunakan yaitu Klebsiella pneumoniae. 


\section{METODOLOGI PENELITIAN}

\section{Waktu dan Tempat Penelitian}

Penelitian ini dilaksanakan pada bulan Mei 2019 sampai September 2019 di Laboratorium Farmasi Lanjut, Fakultas Matematika dan Ilmu Pengetahuan Alam, Universitas Sam Ratulangi.

\section{Alat dan Bahan}

Alat yang digunakan dalam penelitian ini antara lain corong, neraca analitik, gelas ukur, tabung reaksi, Erlenmeyer, beker gelas, cawan petri, magnetic stirrer, homogenizer, kertas saring, pencadang, mikropipet, laminar air flow (N-Biotecck), hot plate, mistar berskala, alumunium foil, jarum ose, autoklaf, inkubator, oven, pipet tetes, batang pengaduk, pot salep, blender, ayakan mesh 100, toples kedap udara, gunting, arloji, pinset, alat tulis, kertas lebel.

Bahan yang digunakan dalam penelitian ini antara lain, lengkuas putih, Nutrien Agar (NA), ciprofloxacin 500 $\mathrm{mg}$, etanol 96\%, kitosan, polisorbat 80, natrium tripolifosfat (Na-TPP), asam asetat, sabun cair, $\mathrm{Na}_{2} \mathrm{SO}_{4}$ anhidrat, larutan standar Mc.Farland $0,5, \mathrm{NaCl}$ steril $0,9 \%, \mathrm{BaCl}_{2} \cdot 2 \mathrm{H}_{2} \mathrm{O}, \mathrm{H}_{2} \mathrm{SO}_{4} 1 \%$, akuades, bakteri yaitu Klebsiella pneumoniae.

\section{Jenis Penelitian}

Jenis penelitian ini ialah penelitian eksperimental dengan sampel ekstrak dari tanaman lengkuas putih yang dibuat menjadi ekstrak nanopartikel dan dilakukan pengujian pada bakteri.

\section{Prosedur Penelitian}

\section{Pengambilan Sampel dan Persiapan Sampel}

Sampel yang digunakan dalam penelitian ini ialah lengkuas putih yang diambil dari kecamatan Wanea, kota Manado, Provinsi Sulawesi Utara. Sampel ditimbang dengan berat $2 \mathrm{~kg}$.
Kemudian dicuci di bawah air yang mengalir, ditiriskan dan dirajang kecilkecil. Setelah itu dikeringkan (dianginanginkan) selama 7 hari. Sampel yang sudah kering kemudian di blender hingga menjadi serbuk yang dihasilkan diayak dengan ayakan mesh 100, hingga diperoleh simplisia.

\section{Ekstraksi}

Metode yang digunakan yaitu metode maserasi. Simplisia lengkuas putih sebanyak $150 \mathrm{~g}$ dimasukkan ke dalam wadah maserasi yang tertutup rapat. Kemudian diekstraksi dengan 750 $\mathrm{mL}$ etanol $96 \%$ pada suhu kamar selama 5 hari sambil sesekali diaduk. Setelah 5 hari sampel disaring dengan menggunakan kertas saring menghasilkan filtrat. Kemudian filtrat diuapkan menggunakan oven, sehingga diperoleh ekstrak kental lengkuas putih.

\section{Pembuatan Larutan Kitosan}

Kitosan ditimbang masing-masing sebanyak 0,5 g dan 0,1 g kemudian kitosan dilarutkan dengan larutan asam asetat 5\% hingga $100 \mathrm{~mL}$ dan diaduk dengan magnetic stirrer hingga larut.

\section{Pembuatan Larutan Na-TPP}

Larutan Na-TPP dibuat dengan menambahkan 0,1 g Na-TPP ke dalam $100 \mathrm{~mL}$ akuades. Larutan tersebut diaduk dengan magnetic stirrer hingga terlarut.

\section{Pembuatan Formulasi Nanopartikel Ekstrak Lengkuas Putih}

Larutan kitosan $0,5 \%$
dimasukkan ke dalam gelas kimia
sebanyak $100 \mathrm{~mL}$. Kemudian larutan
ditambahkan polisorbat 80 sebanyak 1
mL dan diaduk dengan menggunakan
homogenizer dengan kecepatan $1000 \mathrm{rpm}$
selama 10 menit. Setelah itu, pada larutan
kitosan dimasukkan 0,1 g ekstrak
lengkuas puth yang sudah dilarutkan
dalam etanol 96\% sebanyak 5 mL, lalu
diaduk dengan menggunakan


homogenizer dengan kecepatan $3000 \mathrm{rpm}$ selama 30 menit. Setelah itu, campuran larutan ditambahkan dengan larutan $\mathrm{Na}-$ TPP $0,1 \%$ sebanyak $20 \mathrm{~mL}$ lalu dihomogenizer pada kecepatan $4000 \mathrm{rpm}$ selama 90 menit.

\section{Pembuatan Larutan Uji}

Larutan uji dibuat dengan konsentrasi $50 \%$. Konsentrasi ini dibuat dengan cara pengenceran menggunakan rumus dibawah ini :

$$
M_{1} \times V_{1}=M_{2} \times V_{2}
$$

Keterangan :

$\mathrm{M}_{1}=$ Molaritas larutan awal (M)

$\mathrm{V}_{1}=$ Volume larutan awal (ml)

$\mathrm{M}_{2}=$ Molaritas larutan jadi (M)

$\mathrm{V}_{2}=$ Volume larutan jadi (ml)

\section{Pembuatan Media Dasar dan Media Pembenihan}

Ditimbang Nutrien Agar (NA) sebanyak $2.8 \mathrm{~g}$, dilarutkan dalam akuades sebanyak $100 \mathrm{~mL}$ menggunakan labu Erlenmeyer. Kemudian dihomogenkan dengan magnetic stirrer. Media yang telah homogen kemudian disterilkan dengan menggunakan autoklaf pada suhu $121^{\circ} \mathrm{C}$ selama 15 menit. Dibiarkan sampai media cukup dingin. Media dasar dan media pembenihan digunakan dalam pembuatan media pengujian sebagai lapisan dasar dan lapisan kedua (Ortez, 2005).

\section{Regenerasi Bakteri Uji}

Bakteri Klebsiella pneumoniae yang akan diujikan terlebih dahulu harus diregenerasikan. Hal pertama yang dilakukan yaitu membuat media miring nutrient agar (NA). Media (NA) dituangkan ke dalam tabung reaksi, kemudian diletakkan pada posisi miring dan didiamkan hingga agar memadat. Selanjutnya bakteri uji diambil dengan jarum ose steril lalu ditanamkan pada media agar miring dengan cara digoreskan biakan dari stok bakteri ke permukaan agar dan diinkubasi pada suhu $37^{\circ} \mathrm{C}$ selama 24 jam.

\section{Pembuatan Larutan Kontrol Positif dan Kontrol Negatif}

Kontrol positif dibuat dari sediaan obat tablet ciprofloxacin $500 \mathrm{mg}$, dengan cara 1 tablet ciprofloxacin digerus. Setelah itu ditimbang untuk mendapatkan berat pertablet (y), kemudian disetarakan dengan $50 \mathrm{mg}$ ciprofloxacin. Untuk mendapatkan $50 \mathrm{mg}$ ciprofloxacin, maka berat pertablet $(\mathrm{y}) / 500 \times 50 \mathrm{mg}=(\mathrm{x}) \mathrm{mg}$. Lalu dilarutkan dalam akuades hingga 50 $\mathrm{mL}$, selanjutnya dibuat dengan cara diambil $1 \mathrm{~mL}$ larutan dan ditambahkan akuades hingga $10 \mathrm{~mL}$ untuk memperoleh larutan ciprofloxacin $50 \mu \mathrm{g} / 50 \mu \mathrm{L}$. Larutan kontrol negatif digunakan akuades.

\section{Pembuatan Larutan Mc.Farland 0.,5}

Larutan $\mathrm{H}_{2} \mathrm{SO}_{4} 1 \%$ sebanyak 9,95 $\mathrm{mL}$ dicampurkan dengan larutan $\mathrm{BaCl}_{2} \cdot 2 \mathrm{H}_{2} \mathrm{O} 1,175 \%$ sebanyak $0,05 \mathrm{~mL}$ dalam erlenmeyer. Kemudian dikocok sampai terbentuk larutan yang keruh. Kekeruhan ini dipakai sebagai standar kekeruhan suspensi bakteri uji (Borges dan Bresson, 2004).

\section{Suspensi Bakteri}

Suspensi bakteri dilakukan dengan cara bakteri uji yang telah diregenerasi diambil dengan jarum ose lalu disuspensikan ke dalam tabung reaksi berisi $5 \mathrm{~mL}$ larutan $\mathrm{NaCl}$ steril $0,9 \%$. Suspensi yang terbentuk disetarakan kekeruhannya dengan larutan standar Mc farland.0,5.

\section{Uji Aktivitas Antibakteri}

Uji aktivitas antibakteri dilakukan dengan metode sumuran. Media uji dibuat dengan 2 lapisan media agar. Lapisan dasar atau lapisan pertama dibuat dengan menuangkan masing-masing 15 mL NA ke masing-masing 3 cawan petri, kemudian dibiarkan memadat. Setelah 
memadat, permukaan lapisan dasar ditanam 6 pencadang baja yang diatur jaraknya agar daerah pengamatan tidak bertumpu. Kemudian suspensi bakteri dicampurkan ke dalam media pembenihan NA atau lapisan kedua Selanjutnya dituangkan $15 \mathrm{~mL}$ NA pada tiap cawan petri yang diletakan pencadang sebagai lapisan kedua. Setelah lapisan kedua memadat, pencadang diangkat secara aseptik menggunakan pinset dari masing-masing cawan petri, sehingga terbentuk sumur-sumur yang akan digunakan dalam uji bakteri. Sumuran yang terbentuk diisi dengan larutan kontrol dan larutan uji masingmasing 50 $\mu 1$. Selanjutnya semua media di inkubasi dalam inkubator pada suhu $37^{\circ} \mathrm{C}$ selama 24 jam. Diukur diameter zona bening yang terbentuk dengan menggunakan penggaris milimeter.

\section{Pengukuran Zona Hambat}

Pengukuran zona hambat dilakukan pengulangan sebanyak 3 kali pada sisi horizontal dan sisi vertikal lalu dijumlahkan dan dirata-rata. Hasil diameter zona hambat diperoleh dengan cara mengurangi diameter zona bening yang terbentuk disekitar sumuran dengan diameter sumuran. Menurut Davis and Stout (1971) kemampuan daya respon hambatan pertumbuhan bakteri adalah < $10 \mathrm{~mm}$ lemah, 10-15 mm sedang, 16-20 mm kuat, dan > $20 \mathrm{~mm}$ sangat kuat.

\section{HASIL DAN PEMBAHASAN}

\section{Ekstraksi}

Pengambilan sampel lengkuas putih dilakukan di daerah Manado, Kecamatan Wanea, Provinsi Sulawesi Utara. Sampel yang telah diambil, disortasi basah untuk memisahkan kotoran dari lengkuas putih. Kemudian dicuci bersih dengan air mengalir. Sampel basah lengkuas putih diperoleh 2 $\mathrm{kg}$, lalu dipotong kecil-kecil agar mempermudah proses pengeringan. Cara pengeringan dengan diangin-anginkan di dalam ruangan hingga kadar air dalam sampel berkurang. Hal ini agar proses enzimatik dapat dihentikan karena dapat merusak zat aktif. Selain itu, dapat juga mencegah pertumbuhan mikroorganisme. Lengkuas putih yang telah kering dibuat menjadi serbuk simplisia dengan cara diblender kemudian diayak dengan ayakan mesh 100, hingga diperoleh serbuk halus sebanyak $150 \mathrm{~g}$. Penghalusan sampel bertujuan untuk memperluas permukaan sehingga pada saat proses ekstraksi terjadi kontak antara pelarut dan sampel yang lebih efektif serta senyawa dapat terekstraksi dengan optimal.

Serbuk simplisia diekstraksi dengan metode maserasi. Proses maserasi bertujuan untuk memisahkan satu atau dua komponen yang terdapat pada bahan alam dengan bantuan pelarut. Metode maserasi merupakan salah satu metode umum yang lebih sederhana dan mudah. Caranya dengan merendam serbuk simplisia dalam pelarut sehingga pelarut akan menembus dinding sel dan masuk kedalam rongga sel yang mengandung zat-zat aktif sehingga zat aktif akan larut (Harmita, 2008). Penelitian ini, larutan penyari atau pelarut yang digunakan yaitu etanol 96\% sebanyak $750 \mathrm{~mL}$. Etanol digunakan karena dapat menarik senyawa polar dan non polar, serta memiliki daya ekstraksi yang luas sehingga semua metabolit sekunder dapat tersari.

Maserasi dilakukan selama 5 hari sambil sesekali diaduk. Pengadukan bertujuan untuk mempercepat kontak antara sampel dan pelarut. Kemudian larutan disaring menggunakan kertas saring dan diperoleh filtrat $500 \mathrm{~mL}$ dengan warna kecoklatan. Filtrat lengkuas putih diuapkan menggunakan oven dengan tujuan untuk menghilangkan pelarutnya dari proses maserasi sehingga diperoleh ekstrak kental sebanyak 6,8 gram. Ekstrak kental yang dihasilkan 
kemudian diuji dan dibuat menjadi nanopartikel ekstrak lengkuas putih.

\section{Nanopartikel Ekstrak Lengkuas Putih}

Pembuatan nanopartikel ekstrak lengkuas putih dibuat dengan metode gelasi ionik. Metode gelasi ionik ini didasarkan pada interaksi elektrostastik antara grup amina kitosan dan grup muatan negatif polianion seperti natrium tripolifosfat (Na-TPP). Nanopartikel dengan reaksi gelasi ionik mempunyai beberapa keuntungan yakni reaksi mudah, tidak memerlukan pemanasan sehingga kemungkinan rusaknya senyawa aktif bisa dihindarkan. Proses pembuatan formulasi nanopartikel ekstrak lengkuas putih dilakukan dengan cara mereaksikan campuran kitosan, dengan ekstrak lengkuas putih dan natrium tripolifosfat (Na-TPP). Pada penelitian ini memakai kitosan $0,5 \%$ dan Na-TPP $0,1 \%$, dengan rasio $5: 1$ antara berat kitosan dan TPP. Peningkatan rasio kitosan dan TPP, menghasilkan nanopartikel dengan ukuran yang lebih kecil, serta menghasilkan efisiensi penyerapan paling baik dengan struktur nanopartikel yang kompak (Zhang, 2004).

Pencampuran kitosan dengan ekstrak lengkuas putih dan natrium tripolifosfat (Na-TPP), dilakukan secara bertahap. Larutan kitosan 0,5\% ditambah dengan polisorbat 80 sebanyak $1 \mathrm{ml}$ dan diaduk menggunakan magnetic stirrer dengan kecepatan $1000 \mathrm{rpm}$ selama 10 menit. Penambahan polisorbat 80 untuk menstabilkan emulsi partikel dalam larutan dengan cara mencegah timbulnya penggumpalan, serta memperkecil ukuran partikel. Kemudian pada larutan kitosan $0,5 \%$, ditambahkan ekstrak lengkuas putih 0,1 gr yang telah dilarutkan dalam etanol $96 \%$ dan diaduk menggunakan magnetic stirrer dengan kecepatan 3000 rpm selama 30 menit. Setelah itu ditambahkan larutan Na-TPP $0,1 \%$ dan diaduk dengan kecepatan $4000 \mathrm{rpm}$ selama 90 menit. Selama proses pencampuran larutan, peningkatan kecepatan pengadukan bertujuan memperkecil ukuran partikel. Karena semakin cepat proses pengadukan maka semakin kecil ukuran partikel yang diperoleh. Sehingga penelitian ini menghasilkan formulasi nanopartikel ekstrak lengkuas putih sebanyak $125 \mathrm{ml}$.

\section{Pengujian Aktivitas Antibakteri}

Pengujian aktivitas antibakteri dilakukan dengan metode difusi agar khususnya metode sumuran. Metode ini mudah dilakukan dan tidak membutuhkan waktu yang banyak, metode ini memiliki tingkat sensibilitas lebih tinggi dibanding dengan varian cakram. Caranya, media agar yang telah ditanami bakteri uji dibuat sumuran dengan pencadang berdiameter $7 \mathrm{~mm}$ kemudian sumuran tersebut diisi dengan sampel yang akan diuji aktivitas antibakterinya. Sampel dalam sumuran akan berdifusi pada media agar yang telah ditanami bakteri. Pengamatan dari metode ini adalah terbentuknya zona bening di sekitar sumuran setelah media agar yang ditanami bakteri diinkubasi selama 1x 24 jam pada suhu $37^{\circ} \mathrm{C}$. Pada pengujian ini bakteri uji yang digunakan yaitu Klebsiella pneumoniae untuk mengetahui kemampuan daya hambat dari nanopartikel ekstrak lengkuas putih serta ekstrak etanol lengkuas putih pada konsentrasi $50 \%$ dan kitosan $0,1 \%$ termasuk asam asetat 5\%. Hasil pengamatan uji aktivitas antibakteri disajikan pada Tabel 1. 
Tabel 1. Hasil Pengukuran Diameter Daya Hambat

\begin{tabular}{cccccc}
\hline No & Perlakuan & U1 & U2 & U3 & Rata-rata \\
\hline 1 & Nanopartikel & 24 & 20 & 23,6 & 22,5 \\
2 & Ekstrak 50\% & 10 & 9,5 & 10,5 & 10 \\
3 & As.asetat 5\% & 18,8 & 16,3 & 16,7 & 17,2 \\
4 & Kitosan 0,1\% & 15,6 & 17 & 18 & 16,8 \\
5 & $\mathrm{~K}(-)$ & 0 & 0 & 0 & 0 \\
6 & $\mathrm{~K}(+)$ & 22 & 25,9 & 23,7 & 23,9 \\
\hline \multicolumn{5}{c}{ Pada } & \multicolumn{2}{c}{ pengujian } & aktivitas
\end{tabular}
antibakteri, kemampuan daya hambat pertumbuhan bakteri dikategorikan menurut kategori Davis and Stout (1971) yang disajikan pada Tabel 2.

\section{Tabel 2.Kategori daya hambat pertumbuhan bakteri Davis and Stout (1971)}

\begin{tabular}{ccc}
\hline$N_{0}$ & Kategori & Diameter zona bening $(\mathrm{mm})$ \\
\hline 1 & Sangat Kuat & $\geq 20$ \\
\hline 2 & Kuat & $10-20$ \\
\hline 3 & Sedang & $5-10$ \\
\hline 4 & Lemah & $\leq 5$
\end{tabular}

Pengujian ini menggunakan kontrol negatif dan kontrol positif. Kontrol negatif untuk mengetahui ada tidaknya pengaruh pelarut terhadap pertumbuhan bakteri uji. Sehingga diketahui bahwa yang mempunyai aktivitas antibakteri adalah zat uji bukan pelarut (Dwijendra, 2014). Kontrol negatif yang digunakan adalah akuades. Dari hasil pengujian yang dilakukan pada kontrol negatif tidak memperlihatkan terbentuknya zona hambat. Hal ini membuktikan bahwa daya hambat yang terbentuk tidak dipengaruhi oleh pelarut.

$$
\text { Antibiotik ciprofloxacin }
$$

digunakan sebagai kontrol positif untuk membandingkan daya hambat antara obat antibakteri dengan ekstrak nanopartikel lengkuas putih. Pemilihan antibiotik ciprofloxacin sebagai kontrol positif karena ciprofloxacin merupakan antibiotik berspektrum luas. Antibiotik dengan spektrum luas, yaitu antibiotik yang memiliki aktivitas terhadap banyak jenis bakteri, virus, jamur dan protozoa (Sarro, 2001). Penelitian ini memperoleh zona hambat di sekitar sumuran yang diberi ciprofloxacin. Pengukuran aktivitas zona hambat dari kontrol positif diperoleh nilai $23,9 \mathrm{~mm}$.

Hasil pengukuran zona hambat nanopartikel yaitu $22,5 \mathrm{~mm}$. Hal ini menunjukan nanopartikel ekstrak lengkuas putih dan ciprofloxacin memiliki kemampuan daya hambat yang sama pada bakteri Klebsiella pneumoniae. Faktor terbentuknya zona hambat pada nanopartikel dipengaruhi oleh larutan kitosan, yang memiliki kemampuan menghambat bakteri. Ada dua kemungkinan mekanisme kitosan sebagai antibakteri. Yang pertama kitosan menempel pada permukaan sel bakteri membentuk membran polimer yang dapat mencegah masuknya nutrisi masuk ke dalam sel sehingga sel akan mati. Yang kedua kitosan dengan bobot molekul yang rendah dapat masuk ke dalam sel dan meliputi sel. Karena kitosan dapat mengadsorpsi substansi elektronegatif dalam sel mengganggu aktivitas bakteri (Zhang, 2004).

Zona hambat yang dihasilkan ekstrak etanol lengkuas putih pada konsentrasi 50\% lebih kecil daripada nanopartikelnya. Hasil juga menunjukan bahwa ekstrak lengkuas putih dapat menghambat pertumbuhan bakteri uji. Hal ini dibuktikan dengan terbentuknya zona hambat disekitar sumuran dengan hasil pengukuran $10 \mathrm{~mm}$. Ekstrak lengkuas putih konsentrasi 50\%, punya zona hambat yang dihasilkan sebesar 9,16 mm. Hal ini menunjukan bahwa hasil selaras dengan penelitian sebelumnya. Semakin besar konsentrasi 
ekstrak lengkuas putih, maka semakin besar pula diameter zona bening yang terbentuk. Terbentuknya zona hambat pada ekstrak lengkuas putih karena senyawa bioaktif yang terdapat pada ekstrak lengkuas putih (Hasan, 2019). Ekstrak etanol lengkuas merah dan putih positif mengandung golongan senyawa flavonoid, tannin, kuinon dan terpenoid (Kusriani, 2015). Ekstrak lengkuas putih juga mengandung minyak atsiri yang berperan dalam menghambat pertumbuhan bakteri Klebsiella pneumoniae (Sinaga, 2005).

Pada penelitian ini dilakukan juga pengujian terhadap larutan kitosan 0,1\% dan asam asetat 5\%. Tujuannya untuk melihat aktivitas antibakteri pada kitosan dengan konsentrasi rendah serta untuk melihat pengaruh asam asetat terhadap zona hambat yang terbentuk. Hasil pengukuran zona hambat terhadap kitosan $0,1 \%$ yaitu rata-rata $16,8 \mathrm{~mm}$. Sedangkan hasil pengukuran terhadap asam asetat $5 \%$ yaitu rata-rata $17,2 \mathrm{~mm}$. Dari pengukuran di atas, asam asetat memiliki aktivitas antibakteri. Oleh karena itu, ketika digunakan sebagai pelarut kitosan maka efek antibakteri asam asetat tidak dapat diabaikan (Liu, et al., 2006).

\section{KESIMPULAN}

1. Nanopartikel ekstrak lengkuas putih memiliki aktivitas antibakteri untuk menghambat bakteri Klebsiella pneumoniae.

2. Hasil pengukuran zona hambat didapatkan pengukuran rata-rata 22,5 $\mathrm{mm}$ untuk nanopartikel dan $10 \mathrm{~mm}$ untuk ekstrak etanol lengkuas putih pada konsentrasi $50 \%$ sehingga nanopartikel ekstrak lengkuas putih memiliki daya hambat yang lebih efektif.

\section{SARAN}

Berdasarkan penelitian yang telah dilakukan, penulis memberikan saran bahwa perlu dilakukan penelitian lebih lanjut untuk karakterisasi ukuran partikel ekstrak etanol Lengkuas putih dan penelitian pembuatan nanopartikel dengan metode lain.

\section{DAFTAR PUSTAKA}

Agnihotri, S.A., Nadagounda, N.M., Tejraj M.A. 2004. Recent Advances on Chitosan Based Micro and Nanoparticles in Drug Delivery. Journal of Control Release. 22:(100),5-28.

Bhumkar, D.R.,Varsha, B.P. 2006. Studies on Effect of $\mathrm{pH}$ on Crosslinking of Chitosan With Sodium Tripolyphosphate: A Technical Note. AAPS PharmSciTech. 7:(2),1-6.

Borges, M. T., Bresson, W. 2004. Delivery Methods for Introducing Endophitic Bacteria into Maize. Biocontrol. 49:(4),315-322.

Davis, W. W., Stout, T.R. 1971. Disc Plate Methods of Microbiological Antibiotic Assay. Journal Microbiology. 22(4): 659-665.

Duncan, G.A., Michael A.B. 2015. Computational Design of Nanoparticle Drug Delivery Systems for Selective Targeting. Paper Nanoscale. Royal Society of Chemistry

Dwijendra. 2014. Aktivitas Antibakteri dan Karakteristik Senyawa Fraksi Spons Lamellodysidea herbacea yang Diperoleh dari Teluk Manado. Pharmacon 
Jurnal Ilmiah Farmasi 25:(4),2302- 2493.

Harmita dan Radji, M., 2008. Kepekaan Terhadap Antibiotik. Buku Ajar Analisis Hayati, Eds 3. EGC, Jakarta.

Hasan, P. 2019. Uji Daya Hambat Ekstrak Rimpang Lengkuas Putih (Alpinia galanga L. Swartz) Terhadap Pertumbuhan Bakteri Klebsiella pneumoniae Isolat Sputum Pada Penderita Pneumonia Resisten Antibiotik Seftriakson. [Skripsi]. Fakultas Matematika dan Ilmu Pengetahuan Alam, Universitas Sam Ratulangi, Manado.

Hernani, T,M., Christina, W. 2007. Pemilihan Pelarut pada Pemurnian Ekstrak Lengkuas (Alpinia Galanga) secara Ekstraksi. Jurnal Pascapanen. 4:(1),1-8.

Hubler A.W., Onyeama, O. 2010. Digital Quantum Batteries: Energy and Information Storage in Nanovacuum Tube Arrays. Wiley Periodicals, Inc. Research Article. 11:(1),48-55.

Kafshgari, M.H., Mohammad, K., Mobina, K., dan Sahar, K. (2011). Reinforcement of Chitosan Nanoparticles Obtained by an Ionic Crosslinking Process. Iranian Polymer Journal. 20:(5),445456.

Kammona, O., Costas, K. 2012. A Review Recent Advances in Nanocarrier-based Mucosal Delivery of Biomolecules.
Journal of Controlled Release. 161:(3),781-794.

Kurniasari, D. 2016. Pembuatan Dan Karakterisasi Nanopartikel Ekstrak Etanol Temu Kunci (Boesenbergia Pandurata) pada Berbagai Variasi Komposisi Kitosan. [Skripsi]. Fakultas Matematika dan Ilmu Pengetahuan Alam Universitas Negeri Yogyakarta, Yogyakarta.

Kusriani, R.H., Shofia, Z. 2015. Skrinning Fitokimia dan Penetapan Kadar Senyawa Fenolik Total Ekstrak Rimpang Lengkuas Merah dan Rimpang Lengkuas Putih (Alpinia galanga L.), Prosiding Seminar Nasional Penelitian dan PKM Kesehatan . 1:(1),295-302.

Liu, Y., Lotero, E., Goodwin, J. G. Jr, 2006. Synthesis and Pharmacological Activities of Xanthone Derivatives as Alphaglucosidase Inhibitors. Bioorg Med Chem. 14:(16),56-83.

Ortez, J.H. 2005. Manual of Antimicrobial Susceptibility Testing. American Society for Microbiology. USA.

Prasetyorini, A.E., Zainal, H., Rofiqoh, S. 2011. Penerapan Teknologi Nanopartikel Propolis Trigona Spp Asal Bogor Sebagai Antibakteri Escherichia Coli Secara In-Vitro. Jurnal Ekologia. 11:(1),36-43.

Ramadhan, L.O.A.N, Radiman, C.L., Wahyuningrum, D., Suendo, V., Ahmad, L.O., Valiyaavetil, S. 2010. Deasetilasi Kitin Secara Bertahap Dan Pengaruhnya 
PHARMACON- PROGRAM STUDI FARMASI, FMIPA, UNIVERSITAS SAM RATULANGI,

Terhadap Derajat Deasetilasi Serta Massa Molekul Kitosan. Jurnal Kimia Indonesia. 5:(1),17-21.

Sarro, A.D. 2001. Adverse Reactions to Fluoroquinolones. An Overview on Mechanism Aspect. Current Medicinal Chemistry. 8:(4),37184.

Sinaga. E. 2005. Alpinia galangal (L.) P3TO Universitas Nasional, Jakarta.

Taylor, R.A., Todd, P.O., Yasitha, H., Fabienne, B., Gary, R., Evatt, R.H., Xuchuan, J., Sylvain, C.
2013. Feasibility of Nanofluidbased Optical Filters. Optical Society of America. 52:(7),14131422.

Tiyaboonchai, W. 2003. Chitosan Nanoparticles: Apromising System For Drug Delivery. Naresuan University Journal. 11:(3),51-6.

Zhang, et al. 2004. Immobillization of Lasparaginase on the Microparticles of the Natural Silk Sericin Protein and its Characters. Biomaterials. 25:(4),3751-3759. 